Original paper

\title{
The Role of Theatre with Eco-feminist Approach in Combating COVID Pandemic
}

\section{Debkalpa BasuDas ${ }^{1}$}

Received: 16/10/2020/ Accepted: 10/02/2021/ Published online: 23/12/2021

\begin{abstract}
The present COVID-19 pandemic disaster has brought new challenges to women and shown why the environment needs more benevolent treatment. This study argues that Ecofeminism prescribes an effective way to mitigate the problems of women and the environment, by addressing the two problems together. As Eco-feminism is an activist movement, awareness about its core ideas is essential for its successful implementation. This study explores the tribal (Santhal) population in the village 'Baragora' situated at the Purulia District in the State of West Bengal, India, to investigate the effectiveness of theatre as a medium for creating awareness about the core ideas of Eco-feminism. On the basis of some simple statistical analysis, it observes that there exists an overwhelming preference towards theatre for creating awareness irrespective of gender and irrespective of existing concepts about the core ideas of Eco-feminism. Theatre can promote the core ideas about eco-feminism, as an important tool for tackling the COVID-19 situation present and forthcoming.
\end{abstract}

Keywords: theatre, eco-feminism, COVID Pandemic, risk

\section{INTRODUCTION}

Among the many disastrous outcomes of the COVID-19 pandemic, two observations are of particular interest in the present study. On one hand, the world is experiencing a massive increase in violence against women especially domestic violence. On the other hand, due to lockdowns in factories and restrictions on commutations, the environment has become less polluted and has regained much of its long-forgotten colors. These two conditions underline

${ }^{1}$ Research Scholar, Women's Studies Research Centre, University of Calcutta, Kolkata 
the fact that the world has been benevolent neither to women nor to the environment. The feminist perspective addresses the case of women while the environmentalist perspective addresses issues and problems related to physical environment. Eco-feminism addresses both these issues simultaneously and perhaps more effectively. Eco-feminism (see Annexure for a brief introduction to this concept) is a school of thought that emphasizes deprivation or subordination of women as well as nature by patriarchal society. Eco-feminism emerged both as an academic and activist movement (Lorentzen 2002) during the 70s. Being an activist movement for resolving the issues of women and nature simultaneously, eco-feminism requires awareness of its core ideas and propositions at the mass level.

The present study, investigates theatre as a tool for raising or creating awareness about ecofeminism. Using simple statistical methods, the present study strives to determine whether the raising awareness can vary over gender and over pre-existing conception about the core ideas of eco-feminism. The context of gender is important because the patriarchal attitude may not accept a feminist idea whole-heartedly. If people with no prior knowledge about the core ideas of eco-feminism reject theatre as the most powerful medium for creating awareness, then using theatre for creating awareness will hardly be fruitful. Thus the effectiveness of theatre should be judged independently over gender and pre-existing conception about the core ideas of ecofeminism.

This study surveys 205 adult tribal people from Baragora village located in Purulia, West Bengal, India. All the people surveyed in this study belong to the tribe 'Santhal'. The tribal people are the marginalized and indigenous section of the society. Their pre-existing perception about the core ideas of eco-feminism and their choice of the most powerful medium for creating awareness is little influenced by the modern ideas and arguments of the metropolis-centric media. While COVID19 pandemic has also gradually spreading to these distant localities, far from the madding urban crowd, eco-feminist awareness can possibly be handy to combat such a menace and theatre perhaps can play a great role in spreading such awareness.

\section{OBJECTIVES OF THE STUDY}

The present study investigates the influence of theatre over other media in spreading awareness about eco-feminism, gender-wise and over different pre-existing awareness levels about eco-feminism. The propositions of this study are -

IF

(i) greater awareness about eco-feminism can address the present and forthcoming COVID19 threat as a part of disaster management;

AND IF

(ii) theatre can successfully promote awareness about eco-feminism;

\section{THEN}


(iii) theatre as an effective awareness creation mechanism of eco-feminism can help tackle the COVID19 pandemic situation as disaster management.

Proposition (i) above is evident from the existing literature discussed in the next section. The objective of the present paper then rests on investigating if proposition (ii) above holds or not. If the present study can prove the proposition (ii) above, then proposition (iii) can be concluded.

The present study aims to understand how effective theatre is as a medium of creating awareness on eco-feminism for fighting the existing and emerging COVID19 pandemic across gender and across existing perceptions on eco-feminism.

On the basis of the collected data, we shall investigate the following six key questions:

1. What is the nature of the subjects' pre-existing awareness about eco-feminism?

2. What is their choice of medium as the most powerful medium for spreading awareness?

3. How does the awareness about eco-feminism vary over gender?

4. How does the opinion about theatre as the most powerful medium for spreading awareness vary over gender?

5. How does the opinion about the most powerful medium for spreading awareness vary among different types of pre-existing awareness about eco-feminism in general?

6. How does the opinion about the most powerful medium for spreading awareness vary among different types of pre-existing awareness in terms of gender differences?

\section{LITERATURE REVIEW}

\subsection{Women and Environment in the time of Corona}

The Corona virus outbreak started in December 2019 in Wuhan, China (WHO 2020) and it was declared a pandemic in March 2020 (WHO 2020(i)). As of 14 October 2020, the total number of deaths worldwide due to this pandemic stands at about 1.87 million, whereas this virus has infected 38.2 million people. The pandemic as on this date has taken the cruelest form in US, India and Brazil (COVID-19 Dashboard by the Center for Systems Science and Engineering (CSSE) at Johns Hopkins University).

Women worldwide have suffered more than before due to their gendered identity. To cite a few cases - in Jianli County in Hubei, China, one police department reported a tripling of domestic violence in February 2020 in comparison to February 2019, estimating that $90 \%$ cases were related to the COVID-19 spread. In the UK, deaths from domestic abuse between 23 March and 12 April, 2020 more than doubled compared to the average rate in the previous 10 years (Roesch et al. 2020). In Russia, the number of calls to hotline numbers dedicated to domestic violence leapt from just more than 6,000 in March to more than 13,000 in April 2020. 
In Malawi, Africa 46\% of girls are married before age 18 and $9 \%$ before age 15 in general times. In one of the poorest countries, a spike in child marriages was observed when lockdowns began in March (Seo 2020). This evidence points to the fact that this pandemic perhaps has become a more severe disaster for women.

On the other hand, due to the lockdowns of factories and restrictions on many other economic activities of daily life, the environment worldwide has regained its freshness to a great extent. To cite a few cases, a study in India shows that "...COVID-19 has brought a fearful, devastating scourge for human being but it has emerged as a blessing for natural environment providing it a "recovery time". ... The environmental degradation caused by humans is not totally irreversible. In just 1-2 months, "recovery of nature" is being witnessed by everyone. This is a signal for us to understand and react." Additionally, it finds that after this lockdown "the Air quality index (AQI) in all the states of India is now in two figures (indicating moderately good quality of air). Not only air but the rivers of India like Ganga, Yamuna, and Cauvery, etc. have become clean and clear and marine life is visible." (Lokhandwala and Gautam 2020). Another study in Ecuador found a "reduction in NO2 of up to $22-23 \%$ in the most highly populated cities in Ecuador (Quito and Guayaquil) after the lockdown caused by the outbreak of COVID19" (Pacheco et al. 2020).

On the one hand the COVID-19 pandemic has increased violence against women but on the other hand, has forced patriarchy to reduce its violence against nature. Increased violence against women calls for the feminists to fight more forcefully. Reduced violence against nature calls for the environmentalists to show people how inadvertently civilization has dealt with the nature in which it has grown up. As many countries have started 'unlocking' their economic activities, nature may now go back to the perilous condition it was in before the lockdown. Tackling the disaster caused by the COVID-19 with the eco-feminist approach will improve the condition of women and simultaneously safeguard nature from the patriarchal exploitation slowly reappearing with 'unlock'.

\subsection{Eco-feminism}

Eco-feminism is a combined product of the women's liberation movement and the ecological protection movement (Guan 1996). Eco-feminism, a new school of thought was pioneered by the French feminist writer Francoise d' Eaubonne in the early 1970s. It grew during the 1980s and 1990s amongst women from the anti-nuclear, environmental and lesbian-feminist movements (Lorentzen and Eato, 2002). Eco-feminism as an academic discourse did not develop until the mid to late 1980s (e.g. Salleh 1984, Plumwood 1986, Warren 1987). Ecofeminism identifies a variety of approaches through which one can establish or find a connection between the domination of women and domination of nature.

Eco-feminism emerged as a school of thought which tried to solve the ecological crisis from the perspective of gender. Eco-feminism was born when the ruling mode of a totalitarian state 
had been compromised (Ling 2014). Eco-feminism emerged as a critic of modern industrial civilization. Eco-feminism puts much importance on the cultural values of society. Ecofeminism is a field bridging ecological ethics and feminism that seeks to explore the conceptual connections between environmental degradation and sexist oppression (Warren 1997). As ecofeminists claim that ecology is not complete without feminism similarly feminism is incorporeal without the ecological perspective. Ynesta King describes eco-feminism as a holistic way of thinking (King 1989).

Vandana Shiva and Maria Mies are of the opinion that the Western Development Model has converted both nature and women into consumer goods (Braidotti, et al. 1994). Gender, class, reproductive power, and resource distribution have contributed to the development of the inter relation between nature and women (Agarwal 1992).

Sherry B.Ortner first discussed the relationship between nature and women. In her essay "Is Female to Male as Nature is to Culture?" Ortner points out that nature and women are always associated with some cultural symbols (Ortner 1974). "There are at least eight sorts of connections that eco-feminists have identified. These alleged connections provide sometimes competing, sometimes mutually complementary or supportive, analyses of the nature of the twin dominations of women and nature. A casual perusal of these eight alleged connections helps to identify the range and variety of eco-feminist positions on woman-nature connections" (Warren 1991).

Eco-feminism identifies a variety of approaches through which one can establish or find a connection between the domination of women and domination of nature. Maria Mies states that women have always raised their voices or gone for mass movements whenever there was threat of devastation created either naturally or due to atomic the patriarchal society is equally oppressive towards women and nature (Mise 1993).

Women and nature are connected through domination by patriarchal society. In her book Theorizing Patriarchy, Sylvia Walby calls "patriarchy a system of social structures and practices in which men dominate, oppress and exploit women" (Walby 1990). In a patriarchal society, women and nature both are controlled by the patriarchal system. Eco-feminism is an 'awareness' that begins with the realization that the exploitation of nature is intimately linked to Western Man's attitude toward women and tribal cultures..." (Birkeland 1993). Women are the primary sufferers of environmental degradation and forest resource depletion (Louise Fortmann and Dianne Rcheleau 1985).

Eco-feminists believe that it is the "logic of domination", in association with valuehierarchical thinking and value-dualisms that sustains and justify the twin domination over women and nature (Warren 1990). Eco-feminist theory highlights the connection between the oppression of women and the oppression of nature to understand "why the environment is a feminist issue", as well as "why feminist issues can be addressed in terms of environmental concerns" (Gaard 1993). It is important to realize the nature of these connections to 
comprehend the oppression of women and nature. All feminist theories should include an ecological perspective and vice versa (Warren 1987).

From the literature surveyed above, it is evident that violence against women (VAW) and violence against nature (VAN) have not only similarities, but must be resolved simultaneously for the sake of both woman and nature. And since eco-feminism is also an activist movement, awareness about the core ideas proposed by eco-feminism is also essential. The concepts of Violence against Women (VAW) and Violence against Nature (VAN) are briefly described in the Annexure.

\subsection{Eco-feminist Approach in combating the COVID-19 Pandemic}

The COVID-19 situation is so novel that little if any, academic research is available that use eco-feminist approach.

In her article published in feminismindia.org on 1 April 2020, Srishti Gupta summarizes the relation between the COVID-19 outbreak and the eco-feminist approach to deal with it: "The COVID-19 outbreak has exposed the mistreatment of the nonhuman. However, a sweeping indictment of humanity for ecological stress and deterioration internalizes prejudices perpetuated by power structures of capitalism, imperialism, and patriarchy. Eco-feminist thought, therefore, cautions against knee-jerk eco-centric reactions to crises that hurt the marginalized. Instead, it holds the power structures accountable for exploiting both the nonhuman and human. An eco-feminist approach furthers the idea of environmental justice that takes in its fold social and cultural differences" (Gupta 2020).

In explaining the role of eco-feminism in the COVID-19 pandemic, Aryan Rai, a freelance writer, states "The objective is to morph the male-dominated society into a space that acknowledges not only its homogeneous dependency on women and nature but also the damages its patriarchal practices have caused over many decades" (Rai 2020).

\subsection{Theatre for Awareness}

Governments in different countries use theatre for spreading awareness on different issues, like countering HIV AIDS, using the scientific sanitary system, using gas stoves, etc. Theatre has also been used for propaganda and as a form of resistance, a voice against the ruling class. There have been many academic studies on the effectiveness of theatre as a means for promoting awareness.

Christa Blackmon, an American human rights researcher, and educator observes that "human rights activism relies on an ability to tell stories to diverse audiences that will inspire action toward justice. Distributing information through journalism, whether it be traditional or new media, is the standard method of raising awareness" (Blackmon 2017). Favoring theatre over 
other media for creating awareness, she observes, "Live theatrical performances in particular offer an exceptional form of audience engagement that human rights organizations may find more meaningful than the circulation of films or literature. The theater is also a highly adaptable medium, able to be molded over and over according to the vision of its social and cultural location" (Blackmon 2017). On how and why theatre influences people, she remarks, “...in order to achieve both the goals of art and activism, the artists and the audience must be treated as agents of change. Whether the production is commercial or charitable in nature, creators and actors are engaged in the act of speaking truth to power. At the same time, the "spectators" maintain the possibility of relating what they've witnessed outside of the theater" (Blackmon 2017). A study on the effectiveness of theatre as a means to create awareness about VAW "...reveals that the theatre processes... develops cultural values and awareness in communities" (Khan 2017).

Another study on the effectiveness of participatory theatre in sensitizing people about LGBT individuals found that "...participatory theatre has the potential to promote positive change in attitudes toward LGBT individuals" (Logie et al. 2018).

Since ancient times theatres in India have played an immense part in communicating messages, creating awareness against social evils, and even ushering in a revolution. One of the earliest records of theatre in India goes by the name of Natyaveda. It dates back to the Vedic age, where these ancient plays chronicled the events of cosmic creation. These plays, rich in euphonious music, spectacular dance and drama, were full of intricate rituals which were performed by priests, sages, seers and hermits and recreated the early days of the young universe. The first-ever theoretical treatise of these age-old plays was compiled and recorded by a renowned ancient Indian sage known as Bharatmuni. He named his treatise Natyashastra (Science or study of theatre). As days, years, centuries, and millennia went by, the society evolved and so did the theatre. The simple societies gave way to complex social structures that resulted in multiple challenges. The theatre portrayed socio-economic inequality, the caste system, and the plight of tribes like the Santhals. In India, street theatre has played a significant role in spreading awareness of social issues (Gangopadhyay 1996). Some of the works in this field have been done by such groups as the Bengal-based Bahurupee, who staged a Bengali adaptation of Henrik Ibsen's play, A Doll's House (Putul Ghar in Bengali). This play touched on such topics as women seduction and deprivation by patriarchal society. (Gangopadhyay 1996)

From the ancient period, male-dominated society used women as a commodity in the name of religion or politics. Theater has addressed this kind of commodification. Rudraprasad Sengupta wrote a play titled 'Jagyaseni Agnikannya' based on the Kannada play 'Uriya Uyyale' written by H. S. Venkatesh Murthy. Recently Kasba Arghya produced 'Urubhangam', which enthralled the audience. 
The pioneer of Third Theatre, Badal Sircar was a visionary playwright who highlighted the plight of the Santhals and the women in those societies who faced seemingly endless acts of fiendishness (Anuradha 2019).

Under the aegis of Partha Gupta, the director, and designer, the Santhali theatre produced a few outstanding plays viz. Rabindranath Tagore's Red Oleanders and Hnasa Ora Ria Sereng (The song of the Earthen Cottage) which brilliantly depicted the Bengali and Santhali traditions of theatre, rituals and language (Riaz 2019).

A multitude of folk dance and drama groups which were, at times, even antithetical in nature greatly contributed to the enrichment of India's and, therefore, Bengal's theatrical heritage. Chau is a form of folk drama associated with the heritage and culture of Purulia. It is famous worldwide. The specialty of Chau is its informal way of presentation and simplicity. In Chau, the audience has the feeling of oneness with the performer. In the present time, Chau is practiced and enjoyed in this region although not as widely as it used to be in the past.

Theatre is a powerful medium for creating awareness, not a prejudice cherished over the ages; rather, it is a truth established scientifically. Besides, although many studies have been carried out on the effectiveness of theatre in raising awareness about different issues, there is no prior work assessing the impact of theatre on raising awareness, particularly on eco-feminist ideas.

Consequently, in this study, the extent to which theatre is the most powerful medium for creating eco-feminist awareness is investigated on the basis of the opinion of the respondents. this seems justified as a host of previous studies on the effectiveness of theatre in raising awareness show why theatre should be considered as a medium of raising awareness about the core ideas of eco-feminism.

\subsection{Natural Environment in Purulia}

Deforestation has occurred since humans started building their own houses and settling hamlets. By the 19th century, India's population had increased drastically, leading to scale of deforestation, sufficient to change our climate and ocean currents. Environmental destruction across the globe did not spare places like Purulia, a district in the state of West Bengal, India, which hitherto, had enjoyed Mother Nature's blessing.

In 1999, an NGO, known as the Tagore Society for Rural Development along with local residents of the village of Jharbagda in Manbazar-1 block, started planting trees of seventy-two varieties, including fruits, medicinal herbs, timber wood etc. (Sing 2020). Under the auspices of the Japanese government, the process continued for three years until 2002. People from neighboring villages' viz. Kumardih, Birsinghdih, Cheliama, Radhamadhobpur also joined in. The total of 326,000 trees planted during this time possibly reversed the climate-change impacts that have occurred over the past two decades. These measures allegedly brought down 
the mercury level in these areas, reduce soil erosion, ameliorating the quality of the soil, conserving rain water, and bringing back wildlife.

In order to address the immediate effects of deforestation, the near-extinction of indigenous nomadic tribes like Santhal, Savars, Birhors, the disruption of water management, the shortage of food, migration to cities from the villages and the threat to tribal women by human traffickers and flesh traders, the above success story needs to be replicated all over the region The people in the area of study have an idea about violence against nature and why it should be addressed. The environment and ecology play a big part in keeping the social fabric of a place intact and particularly, women safe.

\section{METHODOLOGY: A brief description of the field}

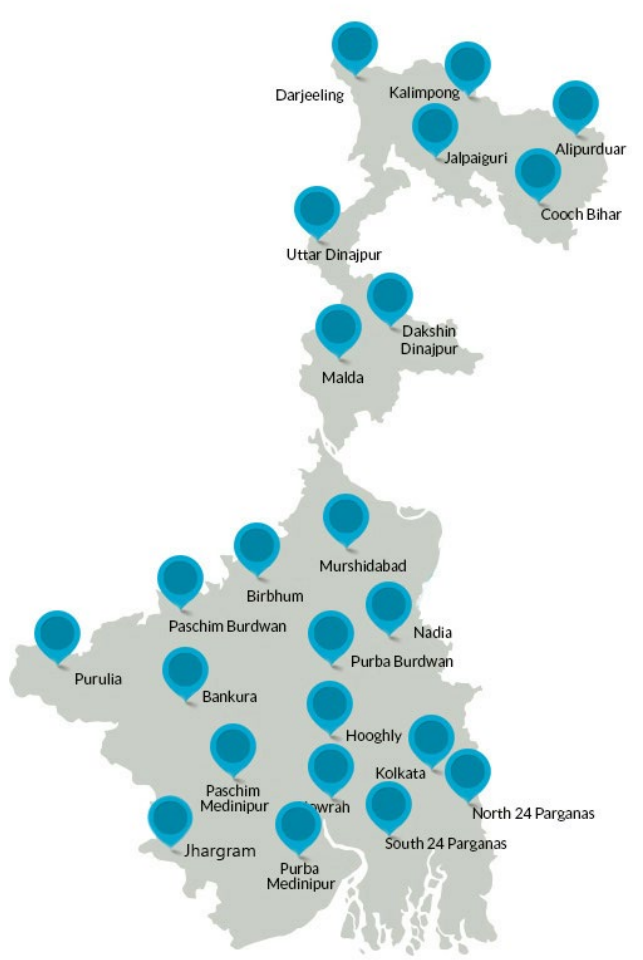

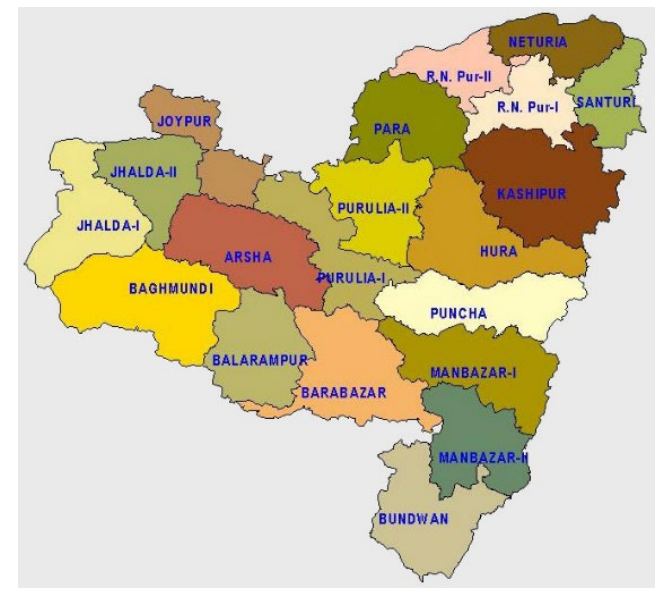

Figure 2. Map of the District of Purulia\& its Administrative Blocks Sources: http://purulia.gov.in

Figure 1. Location of Purulia District in the Map of West Bengal

Sources: https://wb.gov.in/government-district-andlocalgovt.aspx

This research is based on Primary Data, i.e. data collected by the researcher directly based on field survey. Samples have been collected from a village named Baragora from the Purulia District in the State of West Bengal in India. From this village, only adult tribal people were 
surveyed. The sample was drawn using the Convenience Sampling method. In this village, people were not comfortable interacting with an outsider coming from the metropolis of Kolkata. The families showed conservatism when their women were requested to appear to the researcher to answer the survey questions. Therefore, this study adopted convenience sampling rather than other sampling methods.

The village of Baragora is located in the Kashipur Block in Purulia District, near Kalidaha Anchal High School. According to the 2011 Population Census by Govt. of India, its population is 2,327 . The nearest Rail Station is Metyal Sahar, $4 \mathrm{~km}$ West from Baragora.

From this village, 205 tribal people were surveyed.

The researcher conducted survey work with the help of a Local NGO named "Forum for Local Initiatives." Since 2006, this NGO has been working on several environmental protection projects such as afforestation and rainwater preservation with the help of villagers of Baragora. They have staged street plays as one of the media for creating awareness within the community. In the year 1988-90, the members of the "Forum for Local Initiatives" was associated with an environmental project, known as the "Indrabil Watershed Project" funded by "Counterpart Catholic Charities", an initiative of another NGO, the "Marshal Dahar Gaunta."

Researchers selected 205 respondents from various socio-economic backgrounds. Respondents were interviewed using a semi-structured interview schedule. Details on sociodemographic history were included, including such details as age, caste/tribe status, education, current place of residence, and average monthly family expenditure. These variables are thought to profoundly impact the level of eco-awareness of respondents that eventually affects their commitment to the environment. (Chatterjee 2008). In the course of this research several constraints arose, linguistic and terminological problems being the most important. The semistructured protocols applied in the vernacular in face-to-face interviews also provided the respondents with the possibility of misunderstanding. Among the villagers, there has been a long standing misconception about the meaning of "environment". Overcoming this communication problem was a major methodological challenge, hence, qualitative interviewing in a face-to-face context was preferable to the questionnaire technique. Such qualitative interviews were frequently lengthy, and the rigor of quantitative research was lacking. Narrative approaches, as well as group discussions, were also sometimes employed.

For questions $1 \& 2$, the frequency distribution of the answers were investigated using table and diagram. For questions $3,4, \& 5$, cross-tabulation of the two attributes were analyzed using tables and diagrams. Researchers also used $\chi^{2}$-test for independence (see Annexure for a brief introduction to $\chi^{2}$-test for independence). Lastly, for question 6 , researchers investigated frequency distribution from the cross-tabulation of the three attributes using table and diagram.

All the tables and the graphs were prepared using MS Excel. The $\chi^{2}$-tests were carried out using the Chi-square calculator available online for free at https://www.icalcu.com/stat/chisqt est.html. 


\section{Results}

\subsection{Demographic Profile of the Respondents}

\section{Distribution of Respondents according to Gender}

\section{Analysis}

Table labove shows gender distribution of the respondents. The total no of participants were 205. There were 84 (41.0\%) female and $121(59.0 \%)$ male respondents. In this village, people were not sufficiently free to interact with an outsider from Kolkata. The families showed kind of conservatism when their women were requested to appear to the researcher for answering to the survey question as they were reluctant to permit female members of their household from talking to the researchers That is the reason behind the unequal number of male and female respondents in this study. Nevertheless, a good proportion of women respondents could be interviewed too eventually, as evident from Table 1.

Table 1. Frequency distribution of respondents according to gender

\begin{tabular}{|l|c|c|}
\hline Gender & Frequency & Percent \\
\hline Female & 84 & 41 \\
\hline Male & 121 & 59 \\
\hline Total & 205 & 100 \\
\hline
\end{tabular}

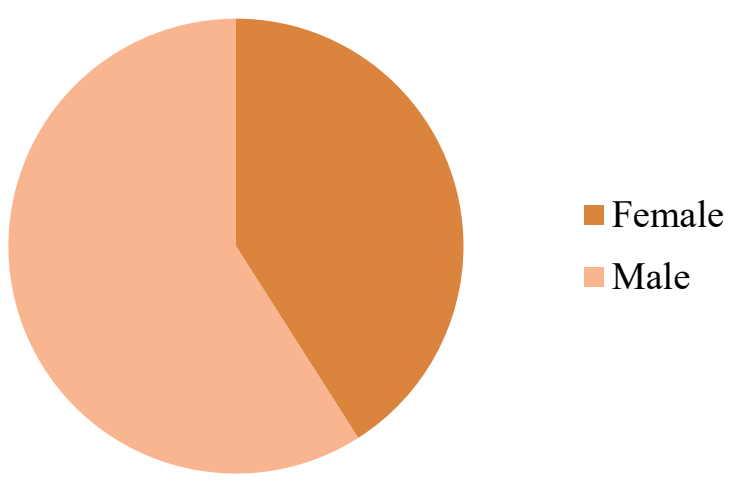

Figure 3. Pie Chart showing the distribution of respondents according to gender

\subsection{Analysis of the Research Questions}

In this section, the answers to the six key questions were sought one by one based on the methodology described earlier.

Nature of pre-existing awareness about eco-feminism: 
Analysis

Table 2 represents the opinion of all respondents about the similarities between Violence against women (VAW) and violence against nature (natural environment) (VAN). Opinions of the respondents are sub-divided into three parts.

$37(18 \%)$ respondents out of 205 total respondents of this study show no concern about said topic.

$47(22.9 \%)$ respondents think there is some difference between the nature of violence on women and violence against the natural environment.

On the other hand, 121 (59\%) respondents believe there is a similarity between the two kinds of violence in society, supporting the eco-feminist views.

It is remarkable that a marginalized rural people living in the lap of nature and sustaining their livelihoods on nature demonstrate such a high awareness of the core idea of ecofeminism. However, considering that $41 \%$ of the respondents either contradict the notion of eco-feminism or show no concern for the issue, there is still ample scope of work.

Table 2. Frequency distribution of awareness about VAW \& VAN

\begin{tabular}{|c|c|c|}
\hline Answers & Frequency & Percent \\
\hline Don't know & 37 & 18 \\
\hline Both are different kind of violence & 47 & 22.9 \\
\hline Both are same kind of violence & 121 & 59 \\
\hline Total & 205 & 100 \\
\hline
\end{tabular}

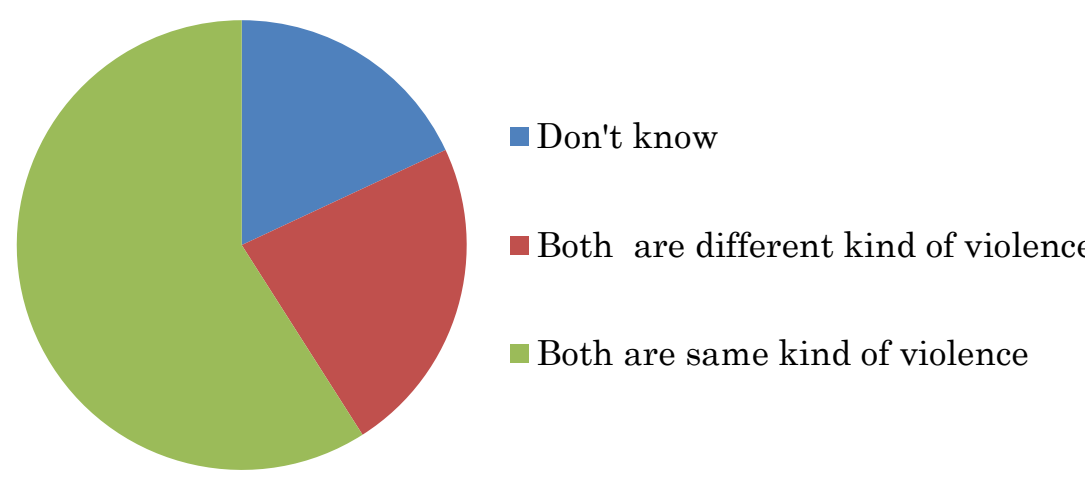

Figure 4. Pie Chart showing distribution of awareness about VAW \& VAN

\section{Choices of medium as the most powerful medium for spreading awareness:}

Analysis 
Table 3 represents the opinion of all respondents about the most powerful medium to resolve the problem of low level of awareness. Here the problem is 'Awareness about Eco-feminism'. The opinion of the respondents is sub-divided into six parts.

$153(74.6 \%)$ respondents believed that theatre is the main medium of creating awareness amongst the masses regarding the issue of Eco-feminism. The second-best medium was Dance which scored only $18(8.8 \%)$ responses.

Assuming that the true effectiveness of a medium in creating awareness is accurately reflected in their opinion about the most powerful medium for creating awareness, this table confirms theatre as the best medium for creating awareness.

Table 3. Frequency distribution of opinion on most powerful medium

\begin{tabular}{|l|c|c|}
\hline \multicolumn{1}{|c|}{ Medium } & Frequency & Percent \\
\hline Drama & 153 & 74.6 \\
\hline Dance & 18 & 8.8 \\
\hline Song & 12 & 5.9 \\
\hline Cinema & 15 & 7.3 \\
\hline Others & 4 & 2 \\
\hline Mixed & 3 & 1.5 \\
\hline Total & 205 & 100 \\
\hline
\end{tabular}

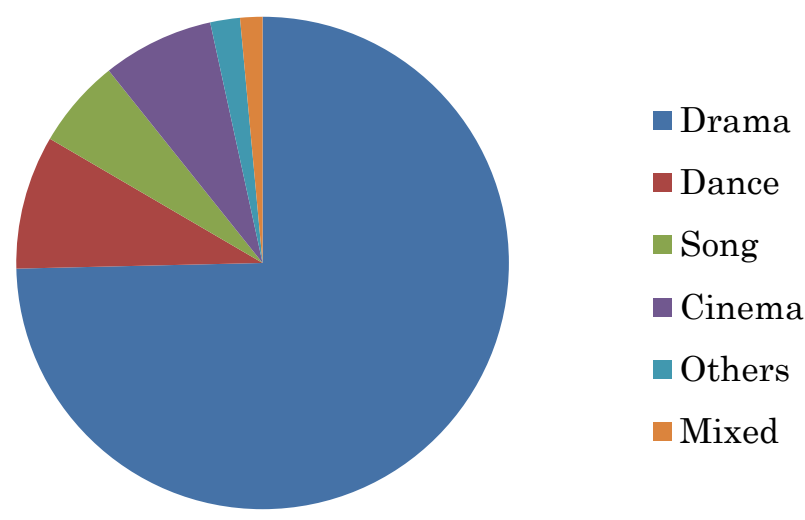

Figure 5. Pie Chart showing distribution of opinions on most powerful medium

The manner of varying awareness about eco-feminism across gender:

Analysis 
Table 4 shows that a high number (52 of the 84 female respondents, $61.9 \%$ of all females) stated that VAN and VAW are the same kind of violence. This shows a slightly higher level of awareness when compared with the relatively low number (69 male respondents $57.0 \%$ of all males) of the 121 who opine that VAN and VAW are the same kind of violence.

The data also shows that 33 of the 121 male respondents $(27.3 \%$ of all males) stated that VAN and VAW are not the same kinds of violence. This shows a low-level awareness compared with the relatively lower number (14 female respondents $16.7 \%$ of all females) of the 84 who opine that VAN And VAW are not the same kinds of violence.

The present study shows that female respondents are somewhat more conscious about the eco-feminism-related issues than their male counterparts. However, whether it is significantly higher or not will be tested later in this study using $\chi^{2}$-test.

There was no prior study regarding the relationship between gender and awareness about eco-feminism. Some studies, Blocker and Eckberg (1997) have found a significant (albeit weak) correlation between gender and environmental concern,

Assuming that awareness about the environment is a proxy of awareness about eco-feminism, the findings of this study support such studies as Aydin \& Cepri (2010), Arcury, Johnson, Milbrata, Mohai (1992), Davidson \& Freuderburg (1996), Shahnawaz (1990), and Sundarajan \& Rajashekhar (1993), Pradhan \& Nagra (2010).

To check whether there is any significant interdependence between Gender and Awareness, a $\chi^{2}$-test is carried out at 2 degrees of freedom and a 5 percent level of significance.

$\mathrm{H}_{0}$ : Gender \& Awareness is independent (i.e., gender does not influence the awareness)

$\mathrm{H}_{1}$ : Gender \& Awareness is dependent (i.e., gender influences the awareness)

The observed $\chi^{2}$ is 3.5334 . The result is not significant at a $5 \%$ level of significance. The $p$ value is .170899 (approx.), i.e., the result will be significant above $17.0899 \%$ level of significance.

So, $\mathrm{H}_{0}$ cannot be rejected.

It can be concluded that, in the scope of this study, the gender difference is not a significant cause of the difference in awareness about the relation between VAW \& VAN. However, in social studies like this, one should not be too skeptical about a little high p-value. The p-value derived in this particular case suggests that there is almost 83 percent chance that $\mathrm{H} 1$ is true, i.e., gender influences the awareness about the relation between VAW and VAN. Coupled with the intuitive analysis of table 4, this suggests that women may be slightly more aware of the relation between VAW and VAN than men. 
Table 4. Frequency distribution of responses against gender

\begin{tabular}{|c|c|c|c|c|c|}
\hline \multirow{2}{*}{\multicolumn{2}{|c|}{$\operatorname{Gender}(\mathrm{X})$}} & \multicolumn{3}{|c|}{$\begin{array}{l}\text { Opinions on Similarities between VAN and VAW } \\
\text { (Y) }\end{array}$} & \multirow{3}{*}{$\begin{array}{r}\text { Total } \\
84 \\
\end{array}$} \\
\hline & & \multirow{2}{*}{$\begin{array}{r}\text { Don't know } \\
18\end{array}$} & \multirow{2}{*}{$\begin{array}{c}\text { Both are } \\
\begin{array}{c}\text { different kind of } \\
\text { violence }\end{array} \\
\end{array}$} & \multirow{2}{*}{ 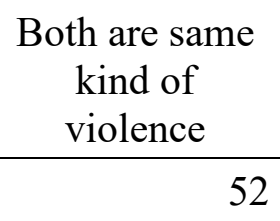 } & \\
\hline Female & Frequency & & & & \\
\hline \multirow{3}{*}{ Male } & \% within $\mathrm{X}$ & 21.40 & 16.70 & 61.90 & 100.00 \\
\hline & Frequency & 19 & 33 & 69 & 121 \\
\hline & \% within $\mathrm{X}$ & 15.70 & 27.30 & 57.00 & 100.00 \\
\hline \multirow[t]{2}{*}{ Total } & Frequency & 37 & 47 & 121 & 205 \\
\hline & $\%$ within $\mathrm{X}$ & 18.00 & 22.90 & 59.00 & 100.00 \\
\hline
\end{tabular}

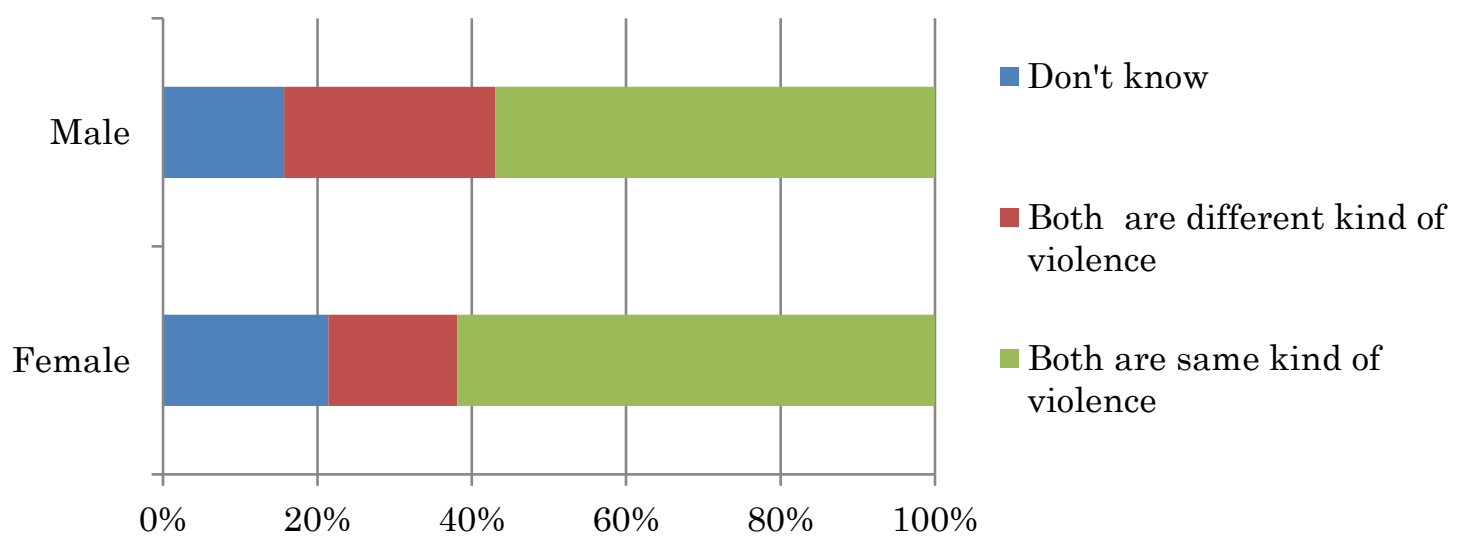

Figure 6. Bar Diagram showing the distribution of respondents according to responses against gender

\section{The manner of varying opinions about the most powerful medium for spreading awareness over gender:}

Analysis

Table 5 above shows that the maximum number of female respondents, i.e., 68 (81\%) out of 84 respondents, believe that theatre is the most popular medium for creating awareness. On the other hand $85(70.2 \%)$ male respondents out of 121 believe that theatre is the best medium for creating awareness. Thus, although both male and female respondents favor theatre the most above all other media for creating awareness, female respondents appear to have a heavier bias towards theatre than their male counterparts. 
Table 5. Frequency distribution of opinion on most powerful medium against gender

\begin{tabular}{|l|l|r|r|r|r|r|r|r|}
\hline \multirow{2}{*}{ Gender (X) } & \multicolumn{7}{|c|}{ Most powerful medium (Y) } & Total \\
\cline { 2 - 10 } & Drama & Dance & Song & Cinema & Others & Mixed & \\
\hline \multirow{4}{*}{ Female } & Frequency & 68 & 6 & 4 & 3 & 1 & 2 & 84 \\
\cline { 2 - 10 } & $\%$ within X & 81.00 & 7.10 & 4.80 & 3.60 & 1.20 & 2.40 & 100.00 \\
\cline { 2 - 10 } & Frequency & 85 & 12 & 8 & 12 & 3 & 1 & 121 \\
\cline { 2 - 10 } & \% within X & 70.20 & 9.90 & 6.60 & 9.90 & 2.50 & 0.80 & 100.00 \\
\cline { 2 - 10 } & Frequency & 153 & 18 & 12 & 15 & 4 & 3 & 205 \\
\cline { 2 - 10 } & \% within X & 74.60 & 8.80 & 5.90 & 7.30 & 2.00 & 1.50 & 100.00 \\
\hline
\end{tabular}

To check whether there is any significant interdependence between Gender and the Choice of Medium, a $\chi^{2}$-test is carried out at 5 degrees of freedom and 5 percent level of significance.

$\mathrm{H}_{0}$ : Gender \& Opinions are independent (i.e., gender does not influence the opinion)

$\mathrm{H}_{1}$ : Gender \& Opinions are dependent (i.e., gender influences the opinion)

The observed $\chi^{2}$ is 5.4552. The result is not significant at a 5\% level of significance. The $p$ value is .362804 (approx.), i.e., the result will be significant above $36.2804 \%$ level of significance.

So, $\mathrm{H}_{0}$ cannot be rejected.

It can be concluded that, in the scope of this study, the difference in gender is not a cause of the difference in opinion about which one is the most powerful medium for spreading awareness. As the p-value is too high, there rests no doubt about this conclusion.

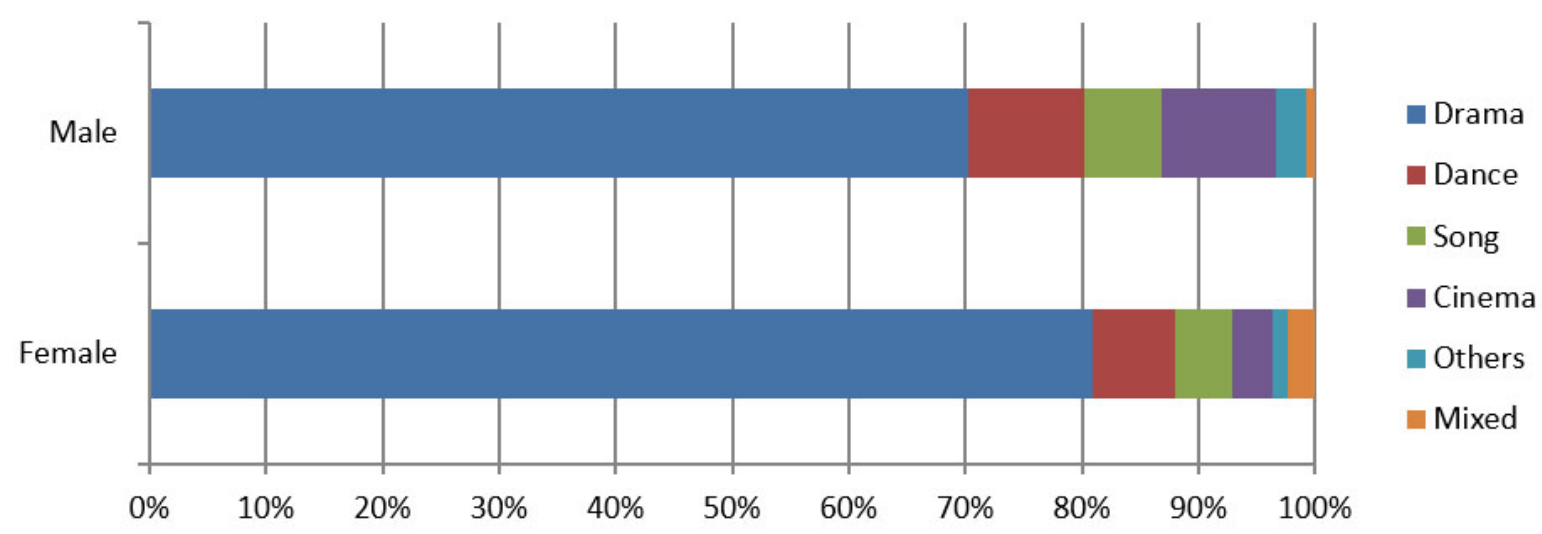

Figure 7. Bar Diagram showing distribution of respondents according to responses against gender 


\section{The nature of varying opinions about the most powerful medium for spreading awareness over different types of pre-existing awareness about eco-feminism:}

\section{Analysis}

Table 6 below shows that out of the 121 respondents, who believe in the core idea of ecofeminism (by supporting that VAW \& VAN are similar kinds of violence), $101(83.5 \%)$ respondents believe that theatre is the most powerful medium for creating awareness. On the other hand, $51.1 \%$ of those respondents who do not believe in the core idea of eco-feminism (by saying that VAW \& VAN are different kinds of violence) think that theatre is the best medium for creating awareness. $75.5 \%$ of the respondents who show confusion or declare their ignorance about eco-feminism's core idea supports that theatre is the most powerful medium for creating awareness. Another important thing to note from this table is that those who, without confusion, expressed their idea in contradiction to eco-feminism have significantly high support for Dance \& Cinema as the most powerful medium.

Thus, it can be concluded that theatre is considered the most powerful medium for creating awareness by all people irrespective of their pre-existing awareness of eco-feminism's core idea.

To check whether there is any significant interdependence between Gender and the Choice of Medium, a $\chi^{2}$-test is carried out at 10 degrees of freedom and 5 percent level of significance.

$\mathrm{H}_{0}$ : Awareness \& Opinions are independent (i.e., pre-existing awareness about eco-feminism does not influence the opinion about the most powerful medium or vice-versa)

$\mathrm{H}_{1}$ : Gender \& Opinions are dependent (i.e., pre-existing awareness about eco-feminism influences the opinion about the most powerful medium or vice-versa)

The observed $\chi^{2}$ is 40.3151 (approx.). The result is highly significant at $5 \%$ level of significance. The $\mathrm{p}$-value is 0.000015 (approx.), i.e. the result is significant above $0.0015 \%$ level of significance.

So, $\mathrm{H}_{0}$ cannot be accepted.

We can draw a conclusion that respondents having pre-existing awareness about ecofeminism prefer theatre as the most powerful medium for spreading awareness about ecofeminism over those who are confused and ignorant about the core ideas of eco-feminism. The confused/less-informed respondents also prefer theatre over other mediums but not as strong as the enlightened ones. 
Table 6. Frequency distribution of respondents according to their opinion on Similarity between VAN \& VAW and most powerful medium for creating awareness

\begin{tabular}{|c|c|c|c|c|c|c|c|c|}
\hline \multirow{2}{*}{\multicolumn{2}{|c|}{$\begin{array}{c}\text { Similarity between VAN } \\
\text { \& VAW (X) }\end{array}$}} & \multicolumn{6}{|c|}{ Medium (Y) } & \multirow{3}{*}{$\begin{array}{r}\text { Total } \\
37\end{array}$} \\
\hline & & \multirow{2}{*}{$\begin{array}{r}\text { Drama } \\
28\end{array}$} & \multirow{2}{*}{$\begin{array}{r}\text { Dance } \\
4\end{array}$} & \multirow{2}{*}{$\begin{array}{r}\text { Song } \\
3\end{array}$} & \multirow{2}{*}{\begin{tabular}{|r|} 
Cinema \\
2 \\
\end{tabular}} & \multirow{2}{*}{\begin{tabular}{|r|} 
Others \\
0 \\
\end{tabular}} & \multirow{2}{*}{$\begin{array}{r}\text { Mixed } \\
0\end{array}$} & \\
\hline \multirow{3}{*}{ Don't know } & Frequency & & & & & & & \\
\hline & $\%$ wi & 75.70 & 10.80 & 8.10 & 5.40 & 0.00 & 0.00 & 100.00 \\
\hline & $\%$ wi & 18.30 & 22.20 & 25.00 & 13.30 & 0.00 & 0.00 & 18.00 \\
\hline \multirow{3}{*}{$\begin{array}{l}\text { Both are } \\
\text { different } \\
\text { kind of } \\
\text { violence }\end{array}$} & Fr & 24 & 11 & 0 & 8 & 3 & 1 & 47 \\
\hline & \% within $\mathrm{X}$ & 51.10 & 23.40 & 0.00 & 17.00 & 6.40 & 2.10 & 100.00 \\
\hline & $\% \mathrm{w}$ & 15.70 & 61.10 & 0.00 & 53.30 & 75.00 & 33.30 & 22.90 \\
\hline \multirow{3}{*}{$\begin{array}{l}\text { Both are } \\
\text { same kind } \\
\text { of violence }\end{array}$} & & 101 & 3 & 9 & 5 & 1 & 2 & 121 \\
\hline & $\%$ wit & 83.50 & 2.50 & 7.40 & 4.10 & 0.80 & 1.70 & 100.00 \\
\hline & $\%$ wi & 66.00 & 16.70 & 75.00 & 33.30 & 25.00 & 66.70 & 59.00 \\
\hline \multirow{3}{*}{ Total } & & 153 & 18 & 12 & 15 & 4 & 3 & 205 \\
\hline & \% within $\mathrm{X}$ & 74.60 & 8.80 & 5.90 & 7.30 & 2.00 & 1.50 & 100.00 \\
\hline & $\%$ within $\mathrm{Y}$ & 100.00 & 100.00 & 100.00 & 100.00 & 100.00 & 100.00 & 100.00 \\
\hline
\end{tabular}

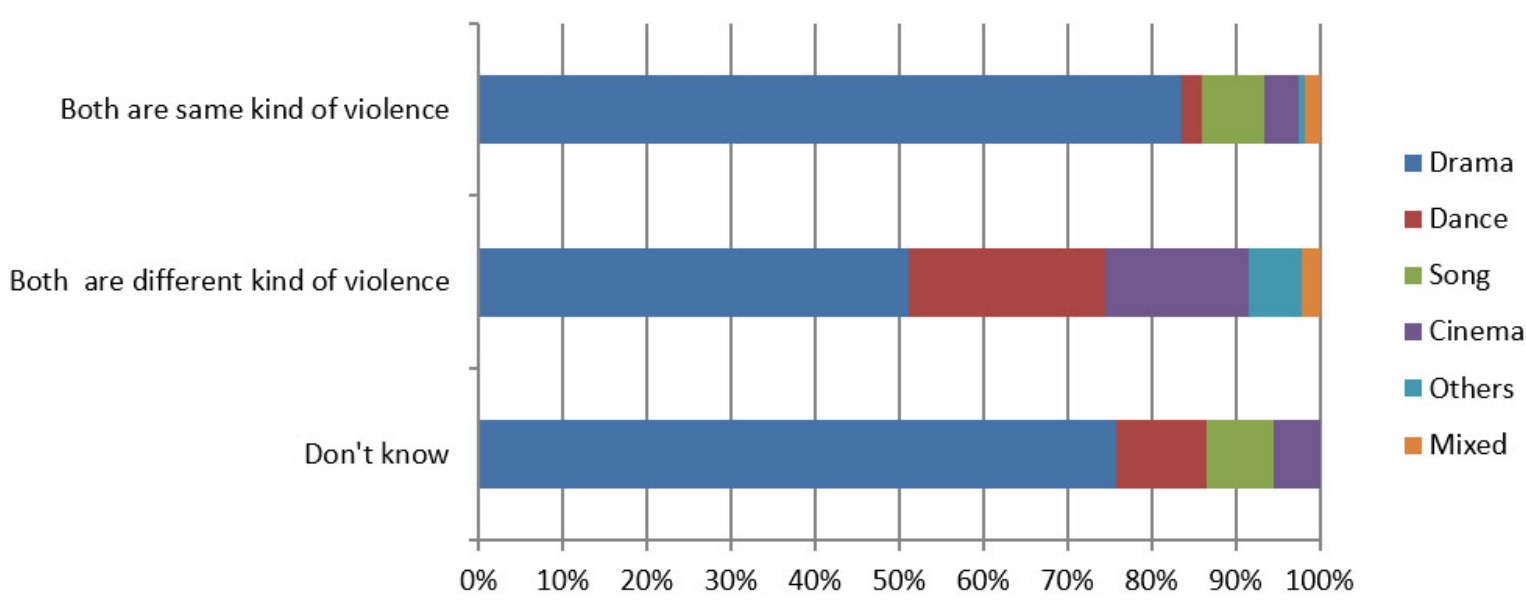

Figure 8. Stack Diagram showing distribution of respondents according to opinion on Similarity between VAN \& VAW and most powerful medium for creating awareness

The manner of varying the opinions about the most powerful medium for spreading awareness over different types of pre-existing awareness about eco-feminism and gender:

Analysis 
Table 7 shows that of all the females who show awareness about the core idea of ecofeminism, $86.5 \%$ consider theatre as the most powerful medium for creating awareness. On the contrary, $81.2 \%$ of all the males aware of the core idea of eco-feminism consider theatre as the most powerful medium for creating awareness. The gender difference among the respondents supporting the eco-feminist notion is not too prominent in selecting theatre as the most powerful medium for creating awareness.

Table 7. Distribution of respondents according to Gender, Opinion on Similarity between VAN \& VAW and Opinion about the Most Powerful medium

\begin{tabular}{|c|c|c|c|c|c|c|c|c|c|}
\hline \multirow[b]{2}{*}{$\begin{array}{l}\text { Gender } \\
\text { (X) }\end{array}$} & \multirow{2}{*}{$\begin{array}{c}\text { Similarity } \\
\text { between VAN } \\
\text { \& VAW } \\
\text { (Y) }\end{array}$} & & \multicolumn{6}{|c|}{ Most Powerful Medium (Z) } & \multirow[b]{2}{*}{ Total } \\
\hline & & & Drama & Dance & Song & Cinema & Others & Mixed & \\
\hline \multirow{12}{*}{ Female } & \multirow{3}{*}{ Don't know } & Frequency & 14 & 2 & 1 & 1 & 0 & 0 & 18 \\
\hline & & $\%$ within $\mathrm{Y}$ & 77.80 & 11.10 & 5.60 & 5.60 & 0.00 & 0.00 & 100.00 \\
\hline & & $\%$ within $\mathrm{Z}$ & 20.60 & 33.30 & 25.00 & 33.30 & 0.00 & 0.00 & 21.40 \\
\hline & \multirow{3}{*}{$\begin{array}{l}\text { Both are } \\
\text { different kind } \\
\text { of violence }\end{array}$} & Frequency & 9 & 3 & 0 & 1 & 1 & 0 & 14 \\
\hline & & $\%$ within $\mathrm{Y}$ & 64.30 & 21.40 & 0.00 & 7.10 & 7.10 & 0.00 & 100.00 \\
\hline & & $\%$ within $\mathrm{Z}$ & 13.20 & 50.00 & 0.00 & 33.30 & 100.00 & 0.00 & 16.70 \\
\hline & \multirow{3}{*}{$\begin{array}{l}\text { Both are same } \\
\text { kind of } \\
\text { violence }\end{array}$} & Frequency & 45 & 1 & 3 & 1 & 0 & 2 & 52 \\
\hline & & $\%$ within $\mathrm{Y}$ & 86.50 & 1.90 & 5.80 & 1.90 & 0.00 & 3.80 & 100.00 \\
\hline & & $\%$ within $\mathrm{Z}$ & 66.20 & 16.70 & 75.00 & 33.30 & 0.00 & 100.00 & 61.90 \\
\hline & \multirow{3}{*}{ Total } & Frequency & 68 & 6 & 4 & 3 & 1 & 2 & 84 \\
\hline & & $\%$ within $Y$ & 81.00 & 7.10 & 4.80 & 3.60 & 1.20 & 2.40 & 100.00 \\
\hline & & $\%$ within $\mathrm{Z}$ & 100.00 & 100.00 & 100.00 & 100.00 & 100.00 & 100.00 & 100.00 \\
\hline \multirow{12}{*}{ Male } & \multirow{3}{*}{ Don't know } & Frequency & 14 & 2 & 2 & 1 & 0 & 0 & 19 \\
\hline & & $\%$ within $Y$ & 73.70 & 10.50 & 10.50 & 5.30 & 0.00 & 0.00 & 100.00 \\
\hline & & $\%$ within $\mathrm{Z}$ & 16.50 & 16.70 & 25.00 & 8.30 & 0.00 & 0.00 & 15.70 \\
\hline & \multirow{3}{*}{$\begin{array}{l}\text { Both are } \\
\text { different kind } \\
\text { of violence }\end{array}$} & Frequency & 15 & 8 & 0 & 7 & 2 & 1 & 33 \\
\hline & & $\%$ within $Y$ & 45.50 & 24.20 & 0.00 & 21.20 & 6.10 & 3.00 & 100.00 \\
\hline & & $\%$ within Z & 17.60 & 66.70 & 0.00 & 58.30 & 66.70 & 100.00 & 27.30 \\
\hline & \multirow{3}{*}{$\begin{array}{l}\text { Both are same } \\
\text { kind of } \\
\text { violence }\end{array}$} & Frequency & 56 & 2 & 6 & 4 & 1 & 0 & 69 \\
\hline & & $\%$ within $Y$ & 81.20 & 2.90 & 8.70 & 5.80 & 1.40 & 0.00 & 100.00 \\
\hline & & $\%$ within $\mathrm{Z}$ & 65.90 & 16.70 & 75.00 & 33.30 & 33.30 & 0.00 & 57.00 \\
\hline & \multirow{3}{*}{ Total } & Frequency & 85 & 12 & 8 & 12 & 3 & 1 & 121 \\
\hline & & $\%$ within $Y$ & 70.20 & 9.90 & 6.60 & 9.90 & 2.50 & 0.80 & 100.00 \\
\hline & & $\%$ within $\mathrm{Z}$ & 100.00 & 100.00 & 100.00 & 100.00 & 100.00 & 100.00 & 100.00 \\
\hline \multirow{12}{*}{ Total } & \multirow{3}{*}{ Don't know } & Frequency & 28 & 4 & 3 & 2 & 0 & 0 & 37 \\
\hline & & $\%$ within $Y$ & 75.70 & 10.80 & 8.10 & 5.40 & 0.00 & 0.00 & 100.00 \\
\hline & & $\%$ within Z & 18.30 & 22.20 & 25.00 & 13.30 & 0.00 & 0.00 & 18.00 \\
\hline & \multirow{3}{*}{$\begin{array}{l}\text { Both are } \\
\text { different kind } \\
\text { of violence }\end{array}$} & Frequency & 24 & 11 & 0 & 8 & 3 & 1 & 47 \\
\hline & & $\%$ within $Y$ & 51.10 & 23.40 & 0.00 & 17.00 & 6.40 & 2.10 & 100.00 \\
\hline & & $\%$ within $\mathrm{Z}$ & 15.70 & 61.10 & 0.00 & 53.30 & 75.00 & 33.30 & 22.90 \\
\hline & \multirow{3}{*}{$\begin{array}{l}\text { Both are same } \\
\text { kind of } \\
\text { violence }\end{array}$} & Frequency & 101 & 3 & 9 & 5 & 1 & 2 & 121 \\
\hline & & $\%$ within $Y$ & 83.50 & 2.50 & 7.40 & 4.10 & 0.80 & 1.70 & 100.00 \\
\hline & & $\%$ within Z & 66.00 & 16.70 & 75.00 & 33.30 & 25.00 & 66.70 & 59.00 \\
\hline & \multirow{3}{*}{ Total } & Frequency & 153 & 18 & 12 & 15 & 4 & 3 & 205 \\
\hline & & $\%$ within $Y$ & 74.60 & 8.80 & 5.90 & 7.30 & 2.00 & 1.50 & 100.00 \\
\hline & & $\%$ within $\mathrm{Z}$ & 100.00 & 100.00 & 100.00 & 100.00 & 100.00 & 100.00 & 100.00 \\
\hline
\end{tabular}




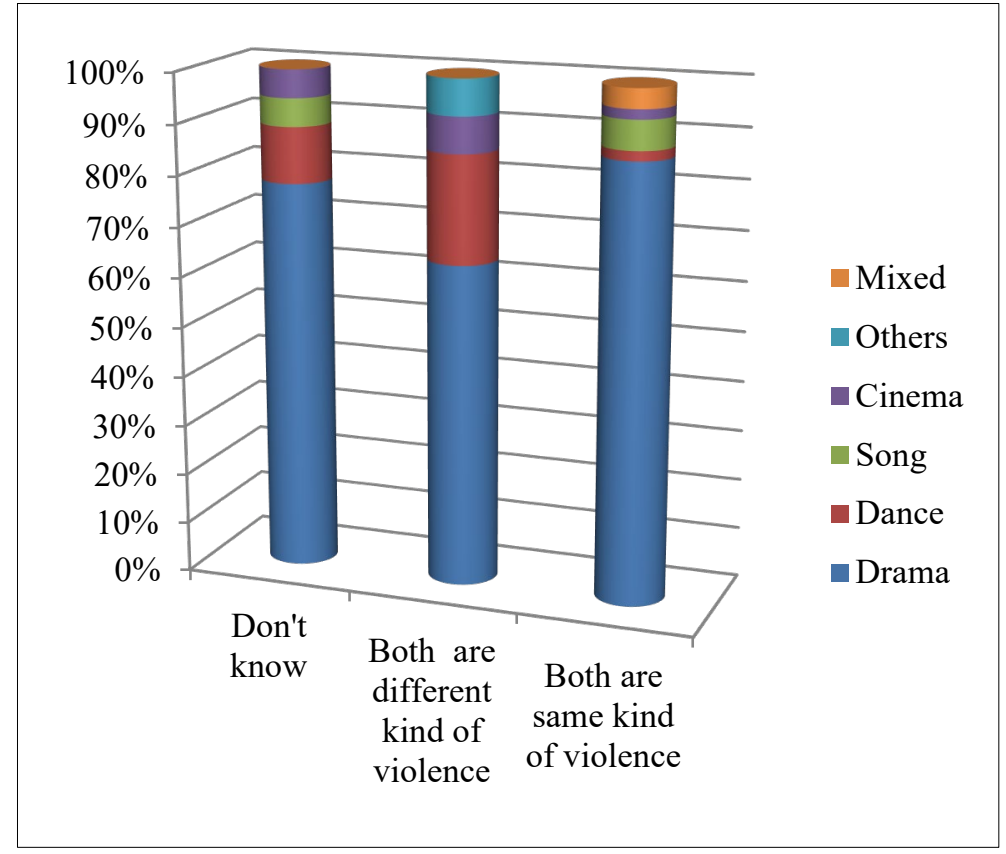

Figure 9. (A): $100 \%$ Stacked Cylinder Diagram showing the percentage distribution of female respondents according to Opinion on Similarity between VAN \& VAW and Opinion about Most Powerful Medium

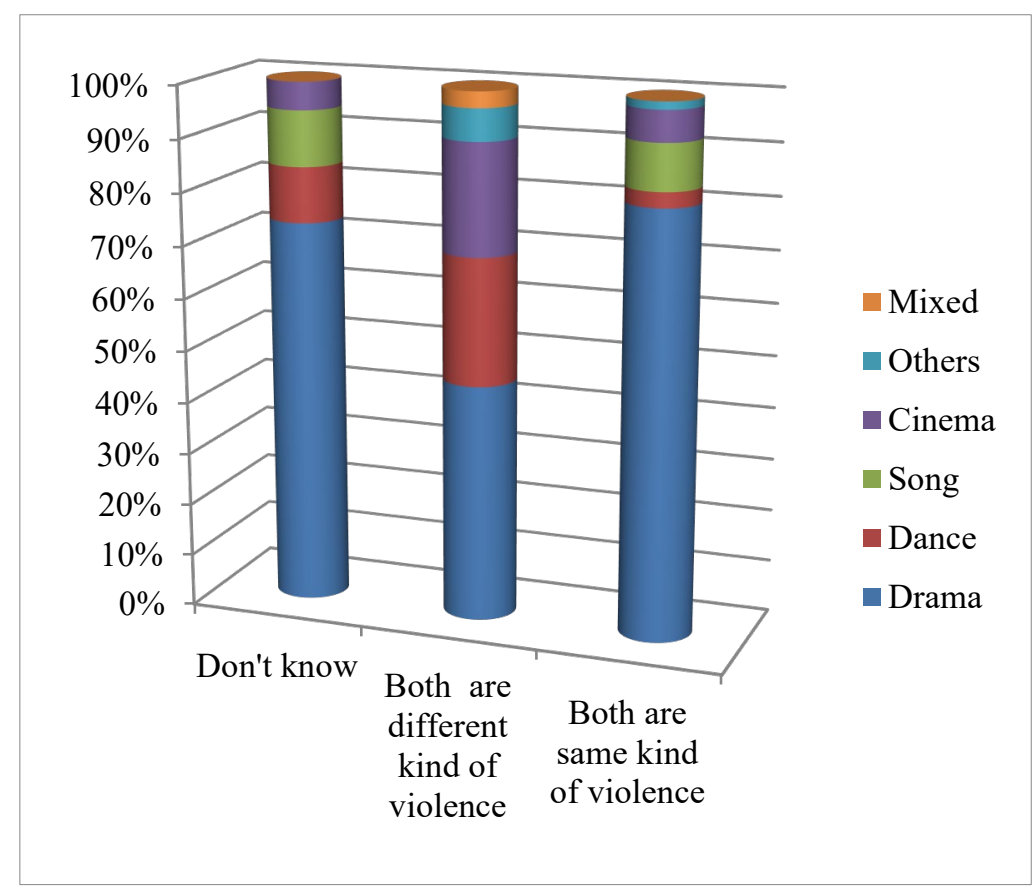

Figure 9. (B): Stacked Cylinder Diagram showing the percentage distribution of male respondents according to Opinion on Similarity between VAN \& VAW and Opinion about Most Powerful Medium 


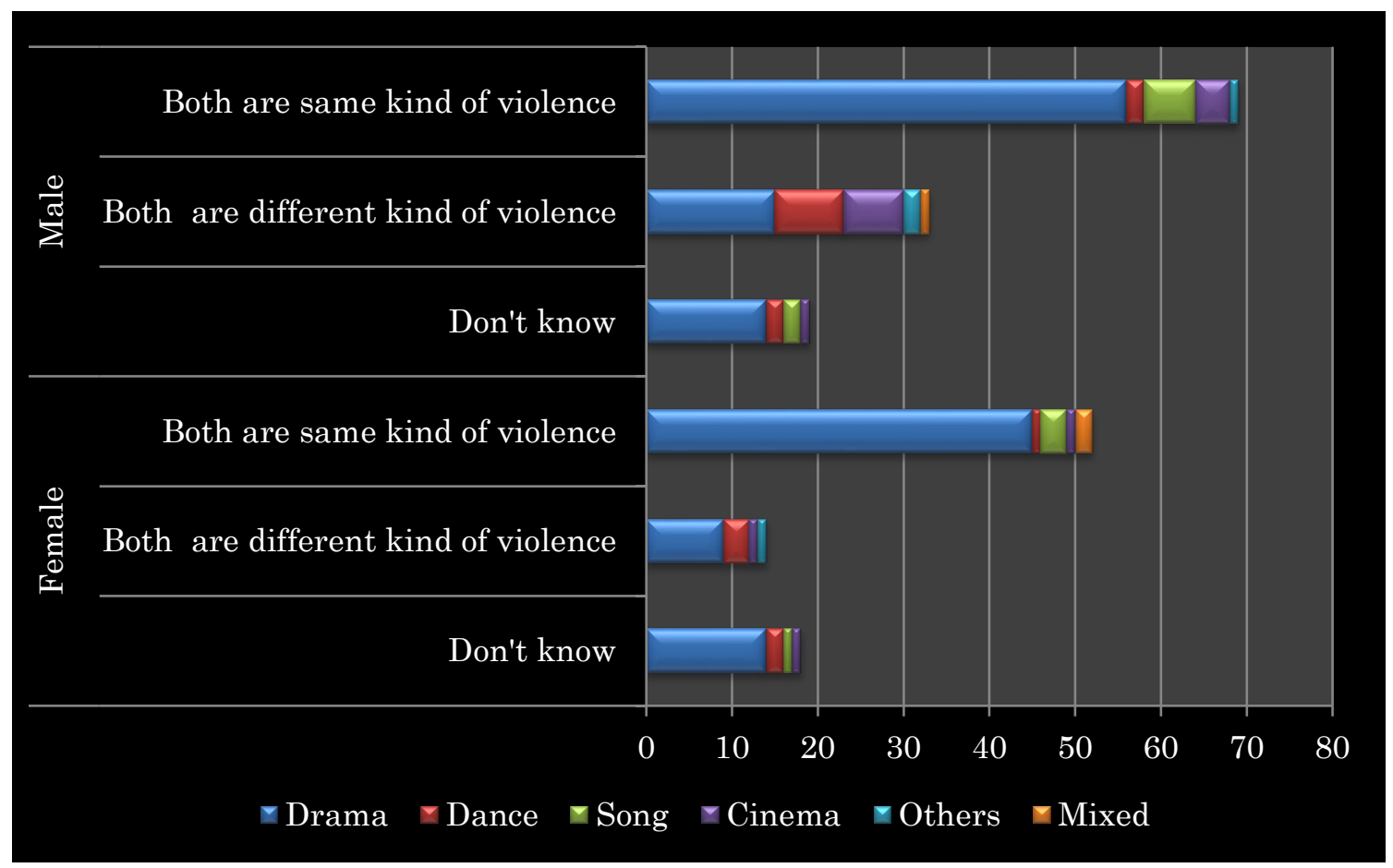

Figure 9. (C): Stacked Column Diagram showing the distribution of respondents according to gender, Opinion about the most powerful medium for creating awareness and Opinion about similarities between VAW \& VAN

Among female respondents who showed confusion about the core idea of eco-feminism, $77.8 \%$ preferred theatre over other mediums for creating awareness. But, $73.3 \%$ of the male respondents having the same confusion preferred theatre over other mediums for creating awareness. Here again, the gender difference is not prominent in choosing theatre.

The idea of eco-feminism is contradicted by favoring the statement that VAW \& VAN are different kinds of violence. The supporters of this contradictory statement should be the prime target (followed by the people who are confused) for spreading awareness about the core idea of eco-feminism. It is found from the table 7 above that $64.3 \%$ of all the female respondents contradicting eco-feminism prefer theatre as the most powerful medium for creating awareness, while $45.5 \%$ of their male counterpart shows preference towards theatre for the same purpose. While $21.4 \%$ of the females contradicting eco-feminism shows preference towards Dance as the most powerful medium for creating awareness and $7.1 \%$ favor Cinema, $24.2 \%$ of their male counterparts favored Dance and 21.2\% favored Cinema. So, it can be concluded that although the respondents who contradict eco-feminism show clear favor for theatre over other mediums for creating awareness, Dance as a medium for the same purpose has somewhat significant preference for both the genders in this group and Cinema has significantly higher preference among the males than the females in the same group. 


\section{CONCLUSIONS}

To address the threats to women arising from the present COVID-19 situation and threats to the environment that has emerged during 'unlock', this study investigated the use ofan ecofeminist approach through theatre.

Analyzing the impact of the COVID-19 pandemic on women and the environment, this study concludes that an eco-feminist approach is useful to combat the harmful consequences of the COVID-19 pandemic on woman. This has been a theoretical exercise.

Adoption of an eco-feminist approach means creation of awareness among masses about the core ideas of eco-feminism. To assess the scope of theatre to create awareness about ecofeminism's core ideas, we took a sample of tribal (Santhal) people from the village Baragora situated in the Purulia District in West Bengal, India. The Santhal people are historically marginalized, but they have a strong cultural heritage. Although these people have employed traditional theater culture, various organizations have used modern forms of theater to enhance reciprocal communication with them. Therefore, when they opine about the effectiveness of theatre in promoting awareness, it is not shaped by their traditional beliefs or notions.

The result suggests that awareness about eco-feminism is a slightly higher amongst females. Female respondents also favored theatre to create awareness more than their male counterparts. Still, in this case, gender is not a significant factor in preferring the best medium for the purpose. The study found that respondents having high eco-feminist awareness prefer theatre, compared to those who are either confused or ignorant about eco-feminism. In fact, the confused/lessinformed respondents also favored theatre as the most powerful medium for spreading awareness but not as strong as those aware of eco-feminism's core idea. However, the relationship between the choice of medium and the pre-existing level of awareness is significant.

In this study, it has further been observed that in choosing the most powerful medium for creating awareness, females prefer theatre more than their male counterparts irrespective of their pre-existing conception about the core idea of eco-feminism. It has also been found that some respondents who contradict eco-feminist ideas show preference for Dance and Cinema as the most powerful medium for creating awareness whether they are male or female. Preference towards theatre is least among those males who contradict the core idea of ecofeminism.

Despite differences in choices as the most powerful medium for creating awareness, people in both gender and having whatever pre-existing perception about the core idea of ecofeminism prefer theatre clearly over other media for creating awareness. This implies that when theatre is used to create awareness on the core ideas of eco-feminism, the producing team will not need to consider whether the audience is male or female and whether they have any preexisting conception about the core ideas of eco-feminism.

Therefore, this study prescribes that theatre should be taken as the medium for creating awareness about the core idea of eco-feminism, whatever be the gender of the target people 
and whatever be their pre-conceived notion about the core idea of eco-feminism. So, the present disastrous situation arising out of the COVID-19 pandemic can be tackled by spreading awareness about eco-feminism by means of theatre.

\section{ACKNOWLEDGMENT}

I am thankful to acknowledge the cooperation of Dr. George James (Professor Emeritus), Department of Philosophy and Religion, University of North Texas at Denton, USA, and Dr. Deba Prashad Chatterjee Associate Professor in Sociology, Maulana Azad College, Kolkata, India for thorough revision of the manuscript of the paper.

\section{REFERENCES}

Abab, O. S. (1997) Performing Life: Case Studies in the Practice of Theater for Development. Bright Printing Press, Zaria, Nigeria.

Agarwal, B. (1992) The gender and environment debate: Lessons from India, Feminist Studies, 18 (1): 119-158 https://doi.org/10.2307/3178217

Agrawal, A. (2016) Representations of Gender and Class, in Contemporary Indian Theatre and Film, pp.4-11.

Anuradha, G. (2019) Revolting Voice of Aboriginal in Badal Sircar's Stal News. IJRAR 6, (2), pp.79-80

Birkeland J. (1993) Ecofeminism: Linking Theory and Practice, in G. Gaard (ed.), Ecofeminism: Women, Animals and Nature, Temple University Press, Philadelphia, P18.

Blackmon, C. (2016) Breaking the fourth wall: theater as human rights activism Using theater to raise awareness on rights issues not only educates the audience-it also creates empathy and connection. OpenGlobalRights https://www.openglobalrights.org/breaking-thefourth-wall-theater-as-human-rights-activism/

Braidotti, R., et al. (1994) Women, the environment and sustainable development: Towards a theoretical synthesis. Published by Zed Books Ltd.

Brammer, L. (1998). Ecofeminism the Environment and Social Movements. New York, NY: Gustavus Adolphus College.

Caldecott, Leonie, and Stephanie Leland, eds. (1983) Reclaim the Earth: Women Speak Out for Life on Earth. London: Women's Press.

Chatterjee, D. P. (2008) Oriental Disadvantage versus Occidental Exuberance: Appraising Environmental Concern in India - A Case Study in a Local Context, International Sociology, 23 (1): 5-33. https://doi.org/10.1177/0268580907084384

COVID-19 Dashboard by the Center for Systems Science and Engineering (CSSE) at Johns H opkins University, https://gisanddata.maps.arcgis.com/apps/opsdashboard/index.html\#/b da7594740fd40299423467b48e9ecf6

Cuomo, C. J. (1992) Unraveling the problems in ecofeminism, Environmental Ethics, 14 (4): 351-363. https://doi.org/10.5840/enviroethics19921446 
Diamond, I., and Orenstein, G. F. eds. (1990) Reweaving the World: The Emergence of Ecofeminism. San Francisco: Sierra Club.

Dunlap, R. E., and Jones, R. E. (2002) Environmental concern: conceptual and measurement issues, in Handbook of Environmental Sociology, eds R. E. Dunlap, and Michelson, W., Westport, CT: Greenwood Press, 482-524.

Dunlap, R. E. (1995) Public Opinion and Environmental Policy, In Environmental Politics and Policy, 2nd ed., ed. J.P. Lester. Durham, NC: Duke University Press, 63-114.

Eaton, H., \& Lorentzen, L. A. (Eds.). (2003). Ecofeminism and Globalization: Exploring Culture, Context, and Religion. New York, NY: Rowman \& Littlefield.

Eaubonne, F. (1974) Le feminism ou la mort [Feminism or Death]. Paris: P. Horay.

Eisler, R. (1990). The Gaia tradition and the partnership future: An ecofeminist manifesto. In I. Diamond \& G. F. Orenstein (Eds.) Reweaving the world: The emergence of ecofeminism. San Francisco: Sierra Club Books pp.23-34.

Epskamp, K. (1989) Theatre in search of social change: the relative significance of different theatrical approaches, Den Haag by CESO

Epskamp, K. P. (1989) Theater in Search of Social Change: The relative significance of different theatrical approaches. The Hague: Center for the Study of Education in Developing Countries.

Fortmann, L., Rocheleau, D. (1985) Women and agroforestry: four myths and three case studies. Agroforestry Systems, 2 (4): 253-272. https://doi.org/10.1007/BF00147037

Freudenburg, W. R. (1991) Rural-Urban Differences in Environmental Concern: A Closer Look, Sociological Inquiry 61 (2): 167-98

Gaard, G. (1993) Living interconnections with animals and nature. In G. Gaard (Ed.), Ecofeminism: Women, animals, nature (pp. 4). Philadelphia, PA: Temple University Press.

Gangopadhyay R. (1996) Natta Mukhapathro, Popular Bengali Theatre Newspaper, Anuli Press, Howrah.

Gramin Vikas Seva Sanshtha GVSS, 2013. Evaluation Study of Tribal/Folk Arts and Culture in West Bengal, Orissa, Jharkhand, Chhatisgrah and Bihar, Working Papers id:5264, eSocialSciences.

Guan, C. L. (1996) A research review of western ecofeminism. Foreign Social Sciences, (2).

Gupta, M. (2014) Gender, Feminist Consciousness, and the Environment: Exploring the "Natural" Connection, Purdue University.

Gupta, S. (2020) "Ecofeminism And COVID-19: Prejudices Of A Hindu Brahminical Society." FII Media Private Limited https://feminisminindia.com/2020/04/01/ ecofeminism-covid-19-prejudices-hindu-brahminical-society/

Harvey, B., James S. and Tony S. (2000) Evaluation of a drama-in-education programme to increase AIDS awareness in South African high school: A randomized community intervention trial, International Journal of STD and AIDS, 11: 105-111. https://doi.org/10.1177/095646240001100207

Riaz, T. (2019) ARAH BAHA A theatre review on the Santali adaptation of Rabindranath Tagore's Raktakarabi (Red Oleanders), by Birbhum Blossom Theatre. 
Khan, Ahmed. (2017) Theatre media as a means of raising awareness on issues of violence against women and women rights: A case study of Bangladeshi and Indian theatre Organizations. (Fellowship with AED).

King, Y. (1983) The Ecology of Feminism and the Feminism of Ecology, in J. Plant, Healing the Wounds: The Promise of Ecofeminism, New Society Publishers, Philadelphia, California pp. 18-28.

Lahar, S. (1991) Ecofeminist Theory and Grassroots Politics

Ling., C (2014) The Background and Theoretical Origin of Eco-feminism, Cross-Cultural Communication, Vol. 10, No. 4, pp. 104-108 http://www.cscanada.net/index.php/ccc/ article/view/4916

Logie, C. H, et al. (2019) Exploring the Potential of Participatory Theatre to Reduce Stigma and Promote Health Equity for Lesbian, Gay, Bisexual, and Transgender (LGBT) People in Swaziland and Lesotho, Health Education \& Behavior, 46 (1): 146-156. doi:10.1177/1090198118760682

Lokhandwala, S. and Gautam, P. (2020) Indirect impact of COVID-19 on environment: A brief study in Indian context, Environmental Research, 188: 109807. doi:10.1016/j.envres.2020.109807

Lorentzen, L. A. (2002) University of San Francisco, and Heather Eaton, Saint Paul University http://www.wloe.org/what-is-ecofeminism.76.0.html

Manukonda, R. (2013) Theater - communication that captivates and enchants, Winter issue, , 4 (2)

McIntyre, Peter. (1998) Puppets with a Purpose: Using Puppetry for Social Change. Written for United Nations Children's Fund, New York, New York.

Mellor, M. (1997) Feminism and Ecology, New York: New York University Press.

Mies, M. (1986) Patriarchy and Accumulation on a World Scale (London: Zed Books Ltd).

Mise. M. (1993) Women have no Fatherland, Ecofeminism, Rawat Publication.

Nanda M. (1991) Is Modern Science a Western Patriarchal Myth? A Critique of the Populist Orthodoxy, Comparative Studies of South Asia, Africa and the Middle East (in South Asian Bulletin ) , 11, 1-2. https://read.dukeupress.edu/cssaame/articleabstract/11/1_and_2/32/34070/Is-Modern-Science-a-Western-Patriarchal-MythA? redirectedFrom $=$ PDF

Nash, R. F. The Rights of Nature: A History of Environmental Ethics. Madison: University of Wisconsin Press.

Ortner, S. (1974) Is female to male as nature is to culture? In M. Z. Rosaldo\& L. Lamphere (Eds.), Women, Culture and Society (pp. 67-88). Stanford, CA: Stanford University Press. http://radicalanthropologygroup.org/sites/default/files/pdf/class_text_049.pdf

Pacheco, H., et al. (2020) $\mathrm{NO}_{2}$ levels after the COVID-19 lockdown in Ecuador: A trade-off between environment and human health, Urban Climate, 34. 100674 https://www. sciencedirect.com/science/article/pii/S2212095520302170

Plant, J. (1990) Searching for common ground: Ecofeminism and bioregionalism. In I. Diamond \& G. F. Orenstein (Eds.), Reweaving the world: The emergence of eco-feminism (pp. 155-164). San Francisco: Sierra Club Books. 
Plavsic, S. (2013) An Investigation of Gender Differences in Pro-environmental Attitudes and Behaviors, Spring 5-10-2013. UCONN LIBRARY. University of Connecticut.

Plumwood, V. (2007) Feminism and the mastery of nature. Chongqing: Chongqing Press

Quinby, L. (1990) "Ecofeminism and the politics of resistance." In I. Diamond \& G. F. Orenstein (Eds.), Reweaving the world: The emergence of ecofeminism (pp. 122-127). San Francisco: Sierra Club Bop. 127;

Rai, A. (2020) The Climate Crisis Could Revive Ecofeminism, LIVEWiRE https://livewire.th ewire.in/gender-and-sexuality/the-climate-crisis-could-revive-ecofeminism/

Roesch, E., et al. (2020) Violence against Women during Covid-19 Pandemic Restrictions, Thebmj, www.bmj.com/content/369/bmj.m1712.

Salleh, A. (1984) Deeper than ecology: The eco-feminist connection, Environmental Ethics, 6 (4): 339-345. https://doi.org/10.5840/enviroethics 1984645

Salleh, A. K. (1992) The eco-feminism/Deep ecology debate: A reply to patriarchal reason, Environmental Ethics, 14 (3): 195-216. https://doi.org/10.5840/enviroethics199214317

Salleh, A. K. (1990) Living with Nature: Reciprocity or Control? in Ethics of Environment and Development, eds. R. and J. Engel (Tucson: University of Arizona Press).

Seo, N. (2020) Violence Against Women Increasing During Pandemic, Voice of America. August 22, https://www.voanews.com/covid-19-pandemic/violence-against-womenincreasing-during-pandemic

Shiva, V. (1988) Staying Alive: Women, Ecology and Development. London, UK: Zed Books.

Shivakumara, K., Mane, S. R., Diksha, J., and Nagaraj, O. (2015) Effect of Gender on Environmental Awareness of Post-graduate Students, British Journal of Education, Society \& Behavioural Science, 8 (1): 25-33. https://doi.org/10.9734/BJESBS/2015/ 16206

Singh, G. (2020) In West Bengal, restoration of a forest gave a village a new lease of life. https://scroll.in/article/951356/

in-west-bengal-restoration-of-a-forest-gave-a-village-a-new-lease-of-life

Smith, A. (2007) RAISING ENVIRONMENTAL AWARENESS THROUGH PERFORMANCE ART, The Evergreen State College. https://citeseerx.ist.psu.edu/ viewdoc/download?doi=10.1.1.630.3465\&rep=rep1\&type=pdf

Starkey, F. and Orme, J. (2001) Evaluation of a primary school drug drama project: Methodological issues and key findings, Health Education Research, 16 (5): 609-622. https://doi.org/10.1093/her/16.5.609

Sundararajan S, Rajshekar S. (1993) Environmental awareness among the higher secondary students, Progressive Education. 67 (3): 41-44.

Tacey D (2009) Edge of the sacred: Jung, psyche, Earth. Daimon, Einsiedeln, Switzerland.

Theodori, G. L., Luloff, A. E., and Willits, F. K. (1998) The Association of Outdoor Recreation and Environmental Concern: Reexamining the Dunlap-Heffernan Thesis, Rural Sociology 63 (1): 94-108. https://doi.org/10.1111/j.1549-0831.1998.tb00666.x

Van Liere, K. D. and Dunlap, R. E. (1980) The Social Bases of Environmental Concern: A Review of Hypotheses, Explanations and Empirical Evidence, Public Opinion Quarterly 44 (2): 181-97. http://www.jstor.org/stable/2748427 
Walby, S. (1990) Theorizing Patriarchy, Basil Blackwell Inc.

Warren, K (2002) Ecofeminism, Ethics and the Environment, 7 (2):12-26

Warren, K. J. (1987) Feminism and Ecology: Making connections, Environmental Ethics, 9 (1): 3-20. https://doi.org/10.5840/enviroethics 19879113

Warren, K. J. (1988) Toward an ecofeminist ethic, Studies in the Humanities. Special issue on feminism, ecology, and the future of the humanities, ed. Patrick Murphy. 15 (2): 140-56.

Warren, K. J. (1990). The power and promise of ecological feminism, Environmental Ethics, 12 (2): 125-146. https://doi.org/10.5840/enviroethics199012221

Warren, K. J. and Cheney, J (1991) Ecological Feminism and Ecosystem Ecology ed. Hypatia, 6 (1), Spring.

World Health Organization (2020) Coronavirus Disease (COVID-19) - Events as They Happe n. https://www.who.int/emergencies/diseases/novel-coronavirus-2019/events-asthey-happen

World Health Organization (2020) Novel Coronavirus-China. https://www.who.int/emergenci es/disease-outbreak-news/item/2020-DON233 